Case Reports in
Gastroenterology
Case Rep Gastroenterol 2021;15:1-8

DOI: 10.1159/000511886

Published online: January 8, 2021 (c) 2021 The Author(s)

Published by S. Karger AG, Basel www.karger.com/crg

This article is licensed under the Creative Commons Attribution-NonCommercial 4.0 International License (CC BY-NC) (http://www.karger.com/Services/OpenAccessLicense). Usage and distribution for commercial purposes requires written permission.

\title{
More than Pus - Primary Hepatic Epithelioid Angiomyolipoma Masquerading as Liver Abscess
}

\author{
Wen Hao Justin Leong Xia Huang Andrew Tan Ennaliza Salazar \\ Department of Gastroenterology and Hepatology, Singapore General Hospital, \\ Singapore, Singapore
}

\section{Keywords}

Hepatic neoplasm · Epithelioid angiomyolipoma $\cdot$ Liver abscess

\begin{abstract}
Hepatic angiomyolipomas (AML) are rare mesenchymal tumours of which the epithelioid type is a rare type with malignant potential. We report a case of primary hepatic epithelioid angiomyolipoma masquerading as liver abscess. A 46-year-old man presented with a 5-day history of fever with epigastric pain and nausea. On the night of admission, his temperature spiked to $39^{\circ} \mathrm{C}$, his blood pressure was $135 / 79$, his heart rate 98, his liver function test revealed albumin $37 \mathrm{~g} / \mathrm{L}$, bilirubin $25 \mu \mathrm{mol} / \mathrm{L}, \mathrm{ALP} 298 \mathrm{U} / \mathrm{L}, \mathrm{ALT}$ $247 \mathrm{U} / \mathrm{L}$, and AST $344 \mathrm{U} / \mathrm{L}$. The clinical suspicion was hepatobiliary sepsis and intravenous ceftriaxone was commenced. CT of the abdomen showed an ill-defined hypodense focus in segment $4 \mathrm{~A} / 8(4.5 \times 3.5 \mathrm{~cm})$ with a minimal fluid component implying a developing abscess or phlegmon. The images were reviewed by a radiologist and showed minimal fluid for percutaneous drainage. MRI of the liver was performed to further characterize the lesion and revealed a solid mass with nodular areas of arterial enhancement and washout, suspicious of neoplasm. Ultrasound-guided liver biopsy of the lesion was performed. Histology showed a histiocyte-rich epithelioid neoplasm consistent with the epithelioid variant of AML. Immunohistochemical staining was positive for human melanoma black 45 , melan-A and cluster of differentiation 68. He successfully underwent liver resection of segment $4 A / 8$ after 6 weeks of antibiotics. To our knowledge, this is the first reported case in the literature of primary hepatic epithelioid angiomyolipoma masquerading as liver abscess.
\end{abstract}




\section{Case Reports in Gastroenterology}

\begin{tabular}{l|l}
\hline Case Rep Gastroenterol 2021;15:1-8 \\
\hline DOI: 10.1159/000511886 & $\begin{array}{l}\text { @ 2021 The Author(s). Published by S. Karger AG, Basel } \\
\text { www.karger.com/crg }\end{array}$ \\
\hline
\end{tabular}

Leong et al.: Hepatic Epithelioid Angiomyolipoma Masquerading as Liver Abscess

\section{Introduction}

Hepatic angiomyolipomas (AML) are rare mesenchymal tumours composed of heterogeneous elements of blood vessels, lipocytes and smooth muscle with a young median age of onset. Classified as perivascular epithelioid cell neoplasms by the World Health Organization in 2002, AML may further be divided into epithelioid, spindle-cell and intermediate subtypes, of which the epithelioid type is a rare type distinct from classical AML in its malignant potential $[1,2]$. While generally considered to be benign historically, several reports have reported its malignant potential $[3,4]$. There are no pathognomonic clinical, laboratory or radiological characteristics of hepatic epithelioid AML (HEAML) with most patients being asymptomatic. Thus, it may commonly be mistaken for other types of hepatic tumours, with the rate of misdiagnosis being high in the absence of histology [2]. On histology, the definitive diagnosis of HEAML is achieved on the display of pathological findings of epithelioid smooth muscle cells, adipocytes and blood vessels in the lesions and immunohistological findings of melanomaspecific markers (human melanoma black 45, melan-A) and smooth muscle markers (smooth muscle actin) in the smooth muscle cells [5]. Within this group, a significant correlation with subsequent aggressive behaviour was seen for tumours larger than $5 \mathrm{~cm}$ with an infiltrative growth pattern, a high nuclear grade, severe pleomorphism, necrosis, and mitotic activity greater than 1 per 50 high-power field [1]. We report a case of primary hepatic epithelioid angiomyolipoma masquerading as liver abscess.

\section{Case Report}

A 46-year-old man presented with a 5-day history of fever with epigastric pain and nausea. Physical examination revealed epigastric tenderness. There was no hepatomegaly, and he was anicteric. His past medical history was negative for cirrhosis or hepatitis. On the night of admission, his temperature spiked to $39^{\circ} \mathrm{C}$, his blood pressure was $135 / 79$, his heart rate was 98 and the liver function test revealed albumin $37 \mathrm{~g} / \mathrm{L}$, bilirubin $25 \mathrm{~mol} / \mathrm{L}$, ALP $298 \mathrm{U} / \mathrm{L}$, ALT $247 \mathrm{U} / \mathrm{L}$ and AST $344 \mathrm{U} / \mathrm{L}$. Amylase was $62 \mathrm{U} / \mathrm{L}$. Inflammatory markers showed CRP 39.6 $\mathrm{mg} / \mathrm{L}$ and procalcitonin $0.43 \mu \mathrm{g} / \mathrm{L}$. Hepatitis B and C serology were negative. The clinical suspicion was hepatobiliary sepsis and intravenous ceftriaxone was commenced. CT of the abdomen showed an ill-defined hypodense focus in segment $4 \mathrm{~A} / 8(4.5 \times 3.5 \mathrm{~cm})$ with a minimal fluid component implying a developing abscess. Images reviewed by a radiologist showed minimal fluid for percutaneous drainage. AFP was $3.6 \mu \mathrm{g} / \mathrm{L}$. MRI of the liver was performed to further characterize the lesion revealed as a solid mass with nodular areas of arterial enhancement and washout with restricted diffusion and heterogeneous T2W hyperintensity and intralesional vascularity, suspicious of neoplasm such as hepatocellular carcinoma (HCC), together with susceptibility at the medial aspect suspicious for gas, representing concomitant infection (Fig. 1a, b). The case was discussed at a multi-disciplinary meeting and the decision was made for targeted liver biopsy of the lesion in view of a possible malignant neoplasm process. An ultrasound-guided liver biopsy of the lesion was subsequently performed. He recovered well and completed a planned 6-week course of antibiotics as an outpatient. At outpatient review, he remained clinically well, and histology showed a histiocyte-rich epithelioid neoplasm consistent with the epithelioid variant of AML together with inflammatory cells including lymphocytes and neutrophils in the background (Fig. 2). Immunohistochemical staining was positive for human melanoma black (HMB)-45, melan-A and cluster of differentiation 68

\section{Karger'=}




\section{Case Reports in Gastroenterology}

\begin{tabular}{l|l}
\hline Case Rep Gastroenterol 2021;15:1-8 \\
\hline DOI: 10.1159/000511886 & $\begin{array}{l}\text { @ 2021 The Author(s). Published by S. Karger AG, Basel } \\
\text { www.karger.com/crg }\end{array}$ \\
\hline
\end{tabular}

Leong et al.: Hepatic Epithelioid Angiomyolipoma Masquerading as Liver Abscess

(Fig. 3-5). A repeat MRI done after completion of antibiotics showed that the previous mass remained stable in size with similar imaging characteristics. Subsequently, he underwent open liver resection of segment 4A/8 successfully. Final histology was that of epithelioid angiomyolipoma measuring $5.3 \mathrm{~cm}$ in its greatest dimension (Fig. 6). Immunohistochemical staining was positive for HMB-45 and smooth muscle actin in the tumour cells (Fig. 7). He recovered uneventfully postoperatively and was last seen well in clinic at the 3-month follow-up.

\section{Discussion}

Our patient was a 46-year-old man who was diagnosed with HEAML from targeted liver biopsy. His demographic fits in with the largest case series of 409 cases where the median age of presentation was 44 years old with the majority presenting as a single tumour [5]. Patients with HEAML are often clinically asymptomatic, HEAML being incidentally discovered during a routine check-up or while conducting imaging examination for other conditions. Rarely, patients present with abdominal distension and pain particularly in the setting of large tumours [5]. To our knowledge, there were no previously reported cases of a possible superimposed liver abscess as initial presentation to date.

In 2002, the World Health Organization recognized perivascular epithelioid cell neoplasms as a group of neoplasms with perivascular epithelioid cell differentiation that include AML, lymphangioleiomyomatosis and clear-cell "sugar" tumour [6, 7]. HEAML is a type of AML composed almost exclusively of epithelioid cells with pronounced abnormal blood vessels and few or no lipocytes [8]. EAML mostly occurs in the kidney, although in rare cases, it develops in the liver, which is known as HEAML [9]. While renal AML is commonly associated with tuberous sclerosis in up to $50 \%$, this association is weaker in HEAML, with studies showing a range between 5 and $15 \%[7,10]$.

\section{Natural History}

Although HEAMLs were previously considered to be benign, clinicians should be aware of their malignant potential [2]. Several cases exhibiting malignant behaviour have been reported. Pathological findings of an atypical epithelioid component with high proliferation activity, p53 immunoreactivity, vascular invasion, portal vein thrombosis, mitotic activity, mutation of p53 and loss of CD117 expression appear to be associated with malignant transformation of hepatic EAML $[11,12]$. Unresected, HEAML carries the risk of a progressive increase in size, eventual rupture of the tumour and poses metastatic risk. Therefore, in patients who are surgical candidates, resection should be considered upfront. In patients who are not suitable for hepatectomy, ablative or interventional therapy could be alternatives although their role and utility are still uncertain. In patients who are conservatively managed, serial scans and close monitoring should be done in view of the potential for local growth and distant metastases.

\section{Imaging Features}

As demonstrated in our case, imaging features from CT or MRI can be challenging to differentiate AML from HCC as they share almost similar imaging characteristics of arterial phase enhancement and decreased enhancement during portal and delayed phase. Classically, AML display high vascularization of a solid tumour with significant macroscopic fatty components

\section{Karger'=}




\section{Case Reports in Gastroenterology}

Case Rep Gastroenterol 2021;15:1-8

\begin{tabular}{l|l}
\hline DOI: 10.1159/000511886 & $\odot 2021$ The Author(s). Published by S. Karger AG, Basel
\end{tabular} www.karger.com/crg

Leong et al.: Hepatic Epithelioid Angiomyolipoma Masquerading as Liver Abscess

[13]. On CT, these often show non-uniformity enhancement in the arterial phase and decreased enhancement during the portal and delayed phase. Similarly, contrast-enhanced MRI shows a low T1WI signal and an increase in T2WI and DWI signal with enhancement in the arterial phase with a subsequent decrease during the portal and delayed phase [5]. Specific unique imaging features supportive of AML include that of a central vessel sign and the presence of an early drainage vein returning into branches of the hepatic or portal vein [5]. Additionally, unlike HCC, AML usually have no capsule, although larger AML can compress the surrounding liver parenchyma to form an incomplete pseudocapsule [5].

Due to the similarities in imaging characteristics with HCC, correct preoperative diagnoses were only correct in $25-52 \%$ of cases [14]. Thus, the final accurate diagnosis often remains inconclusive with imaging alone and histological diagnosis is deemed necessary [14, 15].

\section{Histopathology}

Gross findings of HEAML often show a brown nodule with variegated appearance from underlying intratumoural haemorrhage or necrosis. Because AML comprises various proportions of lipomatous, myomatous, and angiomatous tissues, microscopic examination shows a mixture of blood vessels, specialized smooth muscle cells, and adipose cells with occasional atypical changes. It is this variation of components in a single tumour that reflect the heterogeneity in imaging studies and render accurate diagnosis by imaging alone challenging [11].

Immunohistochemistry is one of the most important diagnostic tools for HEAML. The definitive diagnosis of HEAML depends on the coexistent pathological findings of epithelioid smooth muscle cells, adipocytes and blood vessels in the lesions and positive immunohistochemical findings of melanoma-specific markers (HMB45, Melan-A) and smooth muscle markers (smooth muscle actin) in the smooth muscle cells $[5,10]$. Others have attempted to analyse markers predictive of malignant transformation of HEAML, with pleomorphic and frequent mitosis, p53 immunoreactivity and vascular invasion suggestive of such [12].

\section{Management}

In our patient, immunohistochemical staining was positive for HMB-45 and smooth muscle actin in the tumour cells, but no frank nuclear pleomorphism and other features of predictive malignant transformation of HEAML were seen. However, in view of his young age and symptoms from HEAML, a surgical resection of a 5.3-cm HEAML was appropriate to eliminate his risk of malignant transformation and confer symptom management.

In conclusion, HEAML is a tumour with uncertain malignant potential that is often asymptomatic and first noted incidentally on imaging. While there are unique imaging features such as an early draining vein and the absence of a capsule, imaging alone is often difficult to distinguish from HCC. As such, histology is key to diagnosis, particularly so in non-cirrhotic patients without risk factors of HCC. Due to the small numbers of reported cases, there are no clear guidelines on resection or surveillance; however, in view of the potential for malignant transformation, resection should be considered.

\section{Acknowledgements}

The authors would like to thank Dr. Cheo Fan Foon, Division of Pathology, for his assistance.

\section{Karger'"}




\section{Case Reports in Gastroenterology}

\begin{tabular}{l|l}
\hline DOI: 10.1159/000511886 & $\begin{array}{l}\text { () 2021 The Author(s). Published by S. Karger AG, Basel } \\
\text { www.karger.com/crg }\end{array}$ \\
\hline
\end{tabular}

Leong et al.: Hepatic Epithelioid Angiomyolipoma Masquerading as Liver Abscess

\section{Statement of Ethics}

This project qualified for an IRB waiver in our institution. Written consent to publish this information including images was obtained from the patient. Research was conducted ethically in accordance with the World Medical Association Declaration of Helsinki.

\section{Conflict of Interest Statement}

The authors declare that they have no competing interests.

\section{Funding Sources}

The authors have not declared a specific grant for this research from any funding agency in the public, commercial, or not-for-profit sectors.

\section{Author Contributions}

W.H.J.L. planned, conducted, and wrote the manuscript. X.H.A.T. reviewed the manuscript. E.S. edited and supervised the manuscript.

\section{References}

1 Folpe AL, Mentzel T, Lehr HA, Fisher C, Balzer BL, Weiss SW. Perivascular epithelioid cell neoplasms of soft tissue and gynecologic origin: a clinicopathologic study of 26 cases and review of the literature. Am J Surg Pathol. 2005 Dec;29(12):1558-75.

2 Garoufalia Z, Machairas N, Kostakis ID, Liakea A, Tsaparas P, Liapis G, et al. Malignant potential of epithelioid angiomyolipomas of the liver: A case report and comprehensive review of the literature. Mol Clin Oncol. 2018 Aug;9(2):226-30.

3 Dalle I, Sciot R, de Vos R, Aerts R, van Damme B, Desmet V, et al. Malignant angiomyolipoma of the liver: a hitherto unreported variant. Histopathology. 2000 May;36(5):443-50.

4 Liu J, Zhang CW, Hong DF, Tao R, Chen Y, Shang MJ, et al. Primary hepatic epithelioid angiomyolipoma: A malignant potential tumor which should be recognized. World J Gastroenterol. 2016 May;22(20):4908-17.

5 Mao JX, Teng F, Liu C, Yuan H, Sun KY, Zou Y, et al. Two case reports and literature review for hepatic epithelioid angiomyolipoma: pitfall of misdiagnosis. World J Clin Cases. 2019 Apr;7(8):972-83.

6 Hornick JL, Fletcher CD. PEComa: what do we know so far? Histopathology. 2006 Jan;48(1):75-82.

7 Liu W, Meng Z, Liu H, Li W, Wu Q, Zhang X, et al. Hepatic epithelioid angiomyolipoma is a rare and potentially severe but treatable tumor: A report of three cases and review of the literature. Oncol Lett. 2016 Jun;11(6):3669-75.

8 Mai KT, Perkins DG, Collins JP. Epithelioid cell variant of renal angiomyolipoma. Histopathology. 1996 Mar;28(3):277-80.

9 Eble JN. Angiomyolipoma of kidney. Semin Diagn Pathol. 1998 Feb;15(1):21-40.

10 Tsui WM, Colombari R, Portmann BC, Bonetti F, Thung SN, Ferrell LD, et al. Hepatic angiomyolipoma: a clinicopathologic study of 30 cases and delineation of unusual morphologic variants. Am J Surg Pathol. 1999 Jan;23(1):34-48.

11 Kamimura K, Nomoto M, Aoyagi Y. Hepatic angiomyolipoma: diagnostic findings and management. Int J Hepatol. 2012;2012:410781.

12 Deng YF, Lin Q, Zhang SH, Ling YM, He JK, Chen XF. Malignant angiomyolipoma in the liver: a case report with pathological and molecular analysis. Pathol Res Pract. 2008;204(12):911-8.

\section{Karger'=}




\section{Case Reports in Gastroenterology}

\begin{tabular}{l|l}
\hline Case Rep Gastroenterol 2021;15:1-8 \\
\hline DOI: 10.1159/000511886 & $\begin{array}{l}\text { @ 2021 The Author(s). Published by S. Karger AG, Basel } \\
\text { www.karger.com/crg }\end{array}$ \\
\hline
\end{tabular}

Leong et al.: Hepatic Epithelioid Angiomyolipoma Masquerading as Liver Abscess

13 Kudo M, Okuno T, Tomita S, Kajiwara T, Shirane H, Usuki N, et al. Hepatic angiomyolipoma pre-operatively diagnosed by imaging. J Gastroenterol Hepatol. 1993 Sep-Oct;8(5):483-8.

14 Chang Z, Zhang JM, Ying JQ, Ge YP. Characteristics and treatment strategy of hepatic angiomyolipoma: a series of 94 patients collected from four institutions. J Gastrointestin Liver Dis. 2011 Mar;20(1):65-9.

15 Feng JW, Liu CW, Yang XH, Jiang Y, Qu Z. Hepatic epithelioid angiomyolipoma: a report of two cases and review of the literature. Int J Clin Exp Pathol. 2018 Mar;11(3):1739-45.
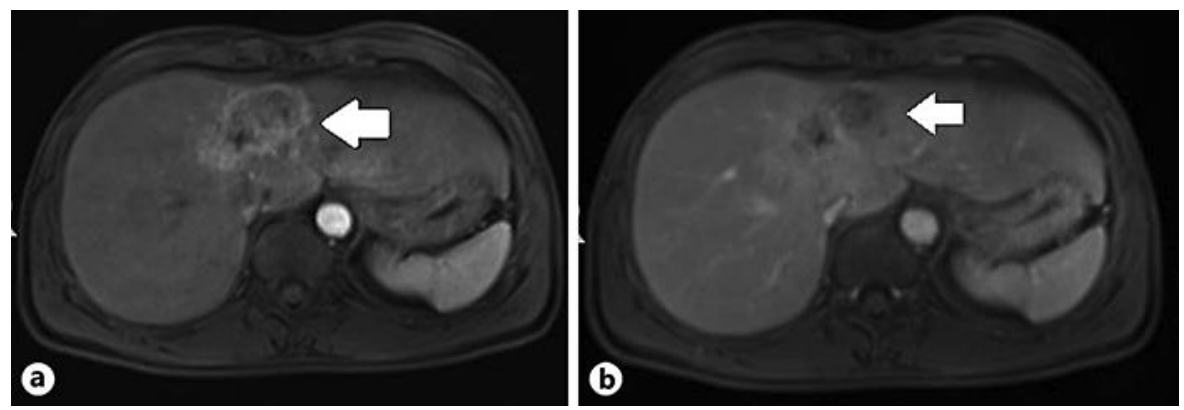

Fig. 1. a MRI of the liver with contrast, arterial phase. b MRI of the liver with contrast, venous phase. Mass in the right hepatic lobe $(4.8 \times 3.1 \times 3.4 \mathrm{~cm}$; white arrow $)$ in segment IV extending to segment VIII appearing relatively solid with nodular areas of arterial enhancement subsequently demonstrating washout.

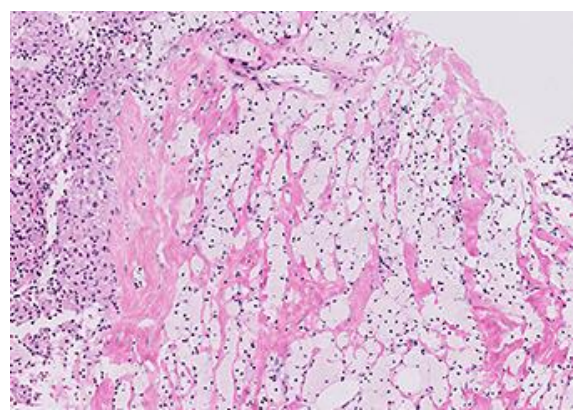

Fig. 2. Liver biopsy, histology ( $\times 10$ magnification). Lesional tissue comprising sheets and aggregates of epithelioid and histiocytoid cells admixed with spindle cells. Inflammatory cells including lymphocytes, neutrophils are present in the background. 
Case Reports in Gastroenterology
Case Rep Gastroenterol 2021;15:1-8

DOI: $10.1159 / 000511886$

(c) 2021 The Author(s). Published by S. Karger AG, Basel www.karger.com/crg

Leong et al.: Hepatic Epithelioid Angiomyolipoma Masquerading as Liver Abscess

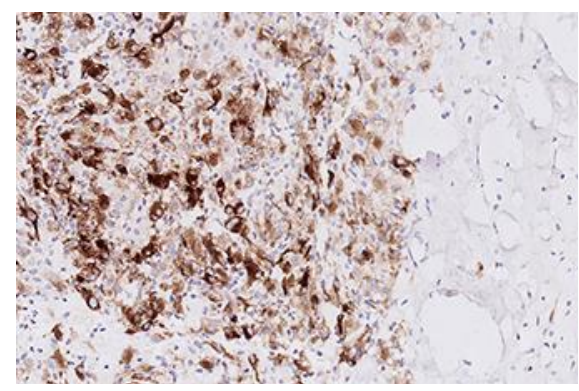

Fig. 3. Positive immunohistochemical staining for human melanoma black (HMB)-45, $\times 20$ magnification.

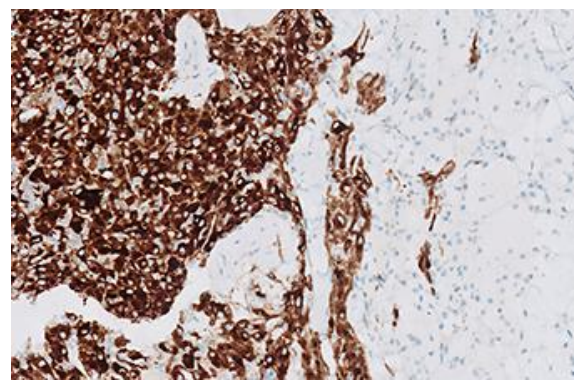

Fig. 4. Positive immunohistochemical staining for melan- $\mathrm{A}, \times 20$ magnification.

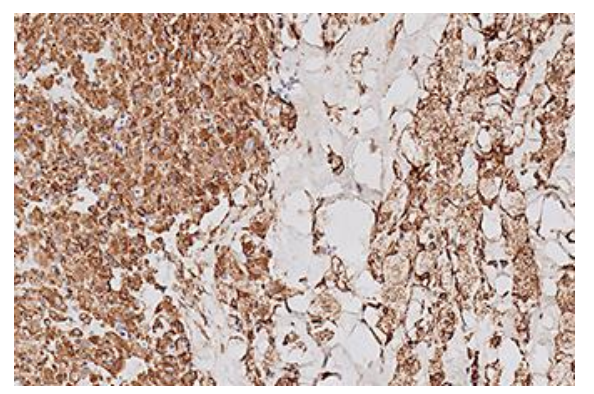

Fig. 5. Positive immunohistochemical staining for cluster of differentiation $68, \times 20$ magnification . 
Case Reports in Gastroenterology
Case Rep Gastroenterol 2021;15:1-8

DOI: $10.1159 / 000511886$

(c) 2021 The Author(s). Published by S. Karger AG, Basel www.karger.com/crg

Leong et al.: Hepatic Epithelioid Angiomyolipoma Masquerading as Liver Abscess

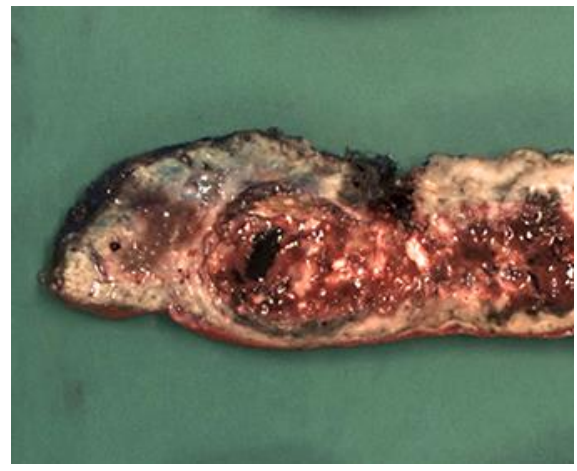

Fig. 6. Segment 4A/8 liver resection, gross pathology. Liver capsular surface is inked red. Liver capsular surface appears smooth, cut sections show a tan yellow lesion with areas of haemorrhage.

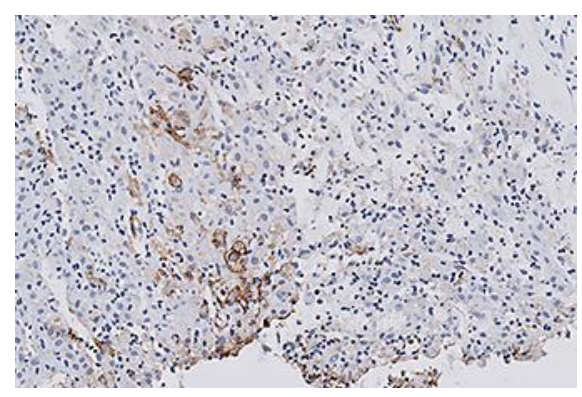

Fig. 7. Positive immunohistochemical staining for smooth muscle actin (SMA), $\times 20$ magnification. 